\title{
„KÉREM, NE LEGYEN TÚL ÉRZÉKENY.” IRODALOMPOLITIKA ÉS KÖNYVKIADÁS RÉVAI JÓZSEF MINISZTERSÉGE IDEJÉN
}

\author{
BELLA KATALIN
}

ELTE BTK KITI, egyetemi tanársegéd

\begin{abstract}
ABSZTRAKT
Tanulmányunk célja annak bemutatása, hogy mennyiben képes, illetve miféle torzulásokkal képes betölteni a tudomány, pontosabban a diszciplínák közül is egy, az irodalomtudomány, azt a kulcsfontosságú szerepet, hogy hiteles ismeretszerzést segítő eszköz legyen, egy, ezt a szerepet súlyosan gátoló történelmi kor, a magyarországi „high stalinism”, azon belül is elsősorban Révai József minisztersége időszakában. A kulturális és tudományos élet pluralizmusa megszüntetésének, a hatalmat gyakorló elitcsoport ideológiája minden eszközzel való terjesztésének és a társadalom indoktrinálásának menete és legfontosabb jellemzői közismertek, ugyanakkor Révai három hatalomgyakorlási módszere közül a „kézi vezérlés” napi múködési mechanizmusát és annak egyedi eseteit eleddig csak részben tárták fel.

A tanulmány tehát az irodalomkritika a könyvkiadással összefonódó kapcsolatrendszerét tárgyalja, azaz az egyes irodalmi művek, szerzők, életművek értékelésének, az irodalmi recepció átalakulásának, a kritika szerepének és a műfordítás alapkérdéseinek jellemző eseteit: azt, hogy hogyan valósult meg a „kézi vezérlés” az irodalomban, illetve miként múködött az alkotók személyével kapcsolatban. Elsőként a rendszerhű írókkal való bánásmód kerül bemutatásra, majd Németh László példáján láthatjuk, hogyan kezelte Révai a belső emigrációba visszavonult, a rendszer mellett hitet tenni nem akaró, de a hatalom számára valamennyire mégis megnyerendőnek tekintett alkotókat, majd az Illyés Gyulához való ambivalens viszony ismertetése újabb adalékkal szolgál Révai irányítási módszereihez. Ezután vázoljuk a Révaival közvetlenül kapcsolatba kerülő, a származás vagy előélet szempontjából megfelelő, közepes vagy szerény színvonalon alkotó írókkal való kapcsolatot, végül kifejtjük, miként foglalkozott Révai nemcsak a kortárs írókkal, hanem a hajdaniakkal is.
\end{abstract}

A fordulat éve után a Magyar Dolgozók Pártja a kultúrpolitikát is lépésrôl lépésre irányítása alá vonta, amely természetszerúleg együtt járt a kulturális intézményrendszer fokozatos monopolizálásával is. ${ }^{1}$

A szellemi élet elitcsoportjainak kezelése összetett módon történt: magát a szellemi teljesítményt formálisan felértékelték, ${ }^{2}$ ugyanakkor az uralkodó szemléletnek ellentmondó értékek és értelmezések térhódítását szigorúan tiltották vagy korlátozták.

Ilyen ellenfélnek pedig elég sokan bizonyulhattak a kommunista párt logikája szerint: az értelmiség jelentős részét ide tartozónak tekintették, még a párttagokat és elkötelezetteket is bizalmatlanul kezelték, megalázták, önmagukkal való megalkuvásra kényszerítették. ${ }^{3}$ 


\section{BELLA KATALiN}

A szellemi élet hétköznapjaiban mindez azt jelentette, hogy többé-kevésbé le kellett mondani a gondolat, a véleménynyilvánítás szabadságáról. ${ }^{4}$

Az intézményi szervezés és az alkalmazott ideológia, a szocialista realizmus magyar viszonyokra érvényes kidolgozása a négyesfogatnak nevezett legfelsőbb vezetés egyik tagjának, Révai Józsefnek feladata lett. Ó lett tehát 1948 és 1953 között a magyar kulturális élet teljhatalmú irányítója.

Mindeközben a kultúrpolitika vagy értelmiségpolitika fokozatosan irodalomközpontú ideológiai irányítássá szűkült, ${ }^{5}$ tehát szovjet mintára kiépültek az írók és a hatalom közötti intézményi formák, a centralizált szellemi élet színterei. ${ }^{6}$

Révai három hatalomgyakorlási módszerrel élt: 1. az országos fórumokon, vagy más fontos alkalmakon elhangzott vagy megjelent kinyilatkoztatások; 2. az egyedi ügyekben tanúsított állásfoglalásai, amelyek megfellebbezhetetlenül váltak a politikai vezetés és az értelmiség közötti párbeszéd korlátaivá, viszonyítási pontjaivá; a három legfontosabb, általa kreált és irányított ,vita” a Lukács-vita, az építészeti vita és a Felelet-vita volt; 3. a szó szoros értelmében vett „kézi vezérlés”, azaz a személyes manipuláció, vagyis, hogy mindenben ki kell kérni a tanácsát, véleményét, s amikor ez nem történik meg, a döntések elhúzódnak. ${ }^{7}$

Hogyan valósult meg tehát ez utóbbi az irodalomban, illetve miként múködött az alkotók személyével kapcsolatban a kézi vezérlés?

1. Itt a források alapján elsőként a rendszerhű írókkal való bánásmód kínálkozik bemutatásra.

Kodolányi Jánosnak még a két háború között tett, félig tréfás kijelentése szellemében - „az író akkor is eleve gyanús, ha a hatalommal tart” - a párttagsági könyvvel is rendelkező írókat éppoly előlegezett gyanakvással kezelte az irodalompolitika, mint azokat, akikkel ideológiai vagy politikai okokból „perben, haragban” állt. ${ }^{8}$

Déry Tibornak a rendszer elsőszámú írójaként való kezelése, de ezzel együtt különccé, különállóvá minősítése jól ismert példa, a viszony sokat idézett summázata Révai kijelentése: „Déry nagy regényíró tehetség, de kommunista létére is fenntartja bizonyos arisztokratizmusát alkotásaiban." "9

E felemás kapcsolat új részleteit világítják meg a Révai miniszteri iratanyagából előkerült, többségében Déry Tibor által írt levelek.

Déry úgy volt szocialista, hogy megmaradt polgárnak, a legnemesebb szocialista és polgári tradíciók őrzőjének. Életvitelében, mentalitásában szabad és művelt polgárként élt, a közéletben szocialistaként, majd kommunistaként vett részt, múveiben pedig szocialistának, illetve kommunistának igyekezett látszani. Belső és külső konfliktusai a fentiekből eredtek. ${ }^{10}$

Déry Tibor írja Révai Józsefnek 1950. június 30-án: „Kedves Elvtársam! Hálás volnék, ha egyszer szakíthatnál magadnak annyi időt, hogy elmondd nekem könyvemrôl való véleményedet, időt illetően természetesen teljesen hozzád alkalmazkodnék. Híved Déry Tibor." 


\section{„KÉREM, NE LEGYEN TÚL ÉRZÉKENY.” IRODALOMPOLITIKA ÉS KÖNYVKIADÁS RÉVAI JÓZSEF MINISZTERSÉGE IDEJÉN}

Révai helyett a titkárnő, Téglás Lászlóné válaszát találjuk az irat mellett: Révai elvtársnak még nem volt ideje elolvasnia könyvét, így a személyes megbeszélést későbbre halasztotta. ${ }^{11}$

A következő levél 1951. március 7-ről jól mutatja, hogy Déry, aki kommunistaként kezdetben üdvözölte a Révai-féle kultúrpolitikát, így megbecsült íróként tartották számon a fordulat után is, elhivatottsága ellenére hogyan került konfliktusba a hatalommal, hogyan bírálta ôt Révai folyamatosan, ${ }^{12}$ a legélesebben talán ezen a második pártkongresszuson, 1951 márciusában.

„Igen tisztelt elvtársam, kongresszusi beszédedben "párton belüli útitársnak« neveztél. Rendkívül bántónak tartottam ezt a definíciót, de nem akartam elsó indulatomban felelni. Ma, egy hét elteltével azonban még éppoly igaztalannak és sértőnek találom s ezért a leghatározottabban tiltakozom ellene. Az elmúlt év tapasztalatai megtanítottak arra, hogy nem igen érsz rá magánlevelekkel foglalkozni, mégis megkérlek arra, hogy mondd vagy magyarázd meg nekem, mire alapítod az arisztokratizmus, illetve a különállás és különcködés vádját, mi igazolja magatartásomban és utolsó éveim irodalmi munkásságában ezt a meghatározást? Így sommásan kimondva csak arra jó, hogy végkép elkedvetlenítsen. Hat év óta amúgy sem túl sok megbecsülésben részesített a Párt s az elmúlt esztendôben - s épp a Felelet megjelenése óta - különösen sok sérelem ért, amelyeket eddig szótlanul s fegyelmezetten fogadtam s tűrtem el; de előbb-utóbb mégis csak feltolakszik a kérdés, hogy tulajdonképp minek dolgozom s, hogy van-e a Pártnak valami haszna a munkámból? Igen hálás lennék neked, ha hozzásegítenél ezeknek a kérdéseknek a tisztázásához."13

Déry bár művei teljes átfogalmazására nem vállalkozott, elvi síkon eleinte több ponton is hajlandó lett volna engedményt tenni az abszurd követeléseknek. ${ }^{14}$ Szégyellte a „realizmus diadalát” pártos énje fölött, a megváltozásra tett ígérete ôszinte volt, „csak” a benne élő alkotó ravaszabb volt nála: az író-Déry éberségét egyre ritkábban tudta kijátszani a párttag-Déry. ${ }^{15} \mathrm{~A}$ források mindemellett azt is mutatják, hogy a (jogosan érzett) sértett büszkeség is arra sarkallta az írót, hogy megmutassa, tehetsége, alkotókészsége, még a lehetetlenre is képes, arra, hogy a fából vaskarika követelést is a megfelelő esztétikai minőségben teljesítse.

Így például 1951 áprilisában Déry egy újabb fejezetet küld Bálint életéből Révainak: arról ír, hogy behozott a regénybe négy új munkásalakot, „valamennyi élesen megrajzolt, hús-vér alak, s mindegyikben már meg van vetve jellemének, társadalmi szerepének, sőt, várható politikai szerepének az alapja, anélkül, hogy a tendencia kilógna belőle. Nem tudom, van-e ma valaki, aki ezt - munkásban! - utánam tudja csinálni!”16

Mire Révai válaszában: „Elolvastam: szép. Persze: a döntő: folytatás és az összkép. Igaz, a munkásfigurák itt elevenek, de meg kell mondjam, erre is érvényes, hogy a nem osztálytudatos munkás elevenebb és élőbb, mint az osztálytudatos."17

A kétpólusú dömpingvitákkal ${ }^{18}$ Révai azt célozta, hogy az alkotók a továbbiakban „kétfrontos harcot” vívjanak mind a bal-, mind a jobboldali múvészi elhajlások ellen, tehát mind a sematikus elemeket, mind pedig a polgári dekadencia maradványait tüntessék 


\section{BELLA KATALIN}

el a magyar irodalomból. Teljes káosz alakult ki, minden irodalmi fórumon szakadatlan és kimeríthetetlennek látszó vita folyt a sematizmusról. Végül senki se tudta már, mi is az a sematizmus. Keszi Imre kijelentette: „Harcoljunk a sematizmus és az antisematizmus ellen!” Ezzel azt óhajtotta javasolni, hogy a párt ne engedjen teret se a sémákra épült, értéktelen, de lobogó pártosságuk miatt elismert irodalmi termékeknek, de ugyanakkor azt se engedje meg, hogy a sémák megszabottságát irodalmi érzékkel, tehetséggel, egyéni hangot hallatva bontsa meg valaki. ${ }^{19}$

Ez az egyik pillanatról a másikra végrehajtandó irányváltási kísérlet természetesen éppoly irreálisnak tűnt a korszak írói számára, mint ahogyan a kulturális vezetés is tudatában volt annak, hogy a megadott új, homályosan körvonalazott direktívák sehogyan sem lesznek követhetők. Minden bizonnyal Déry is tisztában volt ezzel a helyzettel. A következő hónapokban, a sokat emlegetett Felelet-vita közvetlen vagy közvetett hatására létrejövő alkotásai ily módon nem annyira az őszinte önkritika, mint inkább a büntetés, a kirótt penitencia kötelező letudásának igényével íródtak. ${ }^{20}$

Révai József végül ideális megoldásként a Felelet második, de inkább mindkét elkészült kötetének átírását jelölte meg. Mégis, a támadások ellenére is, megmaradt Déry kedvezményezett helyzete, a „börtön” lakályossága. A Felelet-vita után írja a következőket: „Egy kérésem is volna. Külföldre szeretnék menni egy hónapra, szellőzködni, mielőtt dolgozni kezdek, mert tényleg egy kissé megviselt az ügy. Az Írószövetség néhány hete, úgy tudom, beterjesztett egy lengyel útra, bár szívesebben mennék Németországba, ahova már a tavasszal kívánkoztam. Szükségét érzem a környezetváltozásnak, ehhez kérem a segítségedet." ${ }^{21}$

Menjen Lengyelországba! - dönt Révai. ${ }^{22}$

A megvetéssel vegyes leplezetlen ingerültség, amellyel a Rákosi-idők politikai vezetői az úgynevezett „elkötelezett” írókat kezelték, a másodvonal íróival kapcsolatban mutatkozik meg igazán, akik kételyeik elnyomásáért és egyéniségük feláldozásáért cserébe adminisztratív, kis fizetéssel járó, de befolyásos állásokat kaptak, ahol aztán a hatalom kénye-kedve szerint cserélhette őket, írásaikat kitüntetésekkel honorálták, udvari szerzők is lettek. ${ }^{23}$

Erre példa Gergely Sándor esete, akit a Magyar Írók Első Kongresszusa leváltott elnöki tisztségéről, valószínúleg ortodox kommunistasága, baloldali elhajlása miatt. Gergely Sándor 1945-ben tért haza Moszkvából, ezután lett először társelnöke, majd a fordulat éve után egyedüli elnöke az Írószövetségnek. ${ }^{24}$ Mint dogmatikus moszkovita igen aktívan igyekezett saját befolyását növelni, moszkvai látogatásai során igyekezett

Révait kedvezőtlen színben feltüntetni, illetve ő szorgalmazta leginkább az Írószövetség szovjet mintájú átalakítását.

Természetesen a pártvezetés is azon volt, hogy elvégezze a párt központi apparátusában és az államszervezetben szükséges, a Szovjetunióhoz igazodó átalakításokat, de semmiképpen sem úgy, ahogy azt az intrikusnak és tehetségtelennek tartott Gergely Sándor gondolta, ő csak addig tarthatta meg írószövetségi posztját, ameddig a pártközpontbéliek energiáit az Írószövetség átszervezésénél fontosabbnak ítélt feladatok kötötték le. 


\section{„KÉREM, NE LEGYEN TÚL ÉRZÉKENY.” IRODALOMPOLITIKA ÉS KÖNYVKIADÁS RÉVAI JÓZSEF MINISZTERSÉGE IDEJÉN}

A szovjetizáció beteljesedése után azonban már nem maradt más hátra, minthogy az írókongresszuson is szentesítsék a változásokat. Ebbe beletartozott a balos fertőzöttségű írószövetségi vonal korrigálása is, Révai elképzelése szerint. ${ }^{25}$ Így került sor Gergely Sándor leváltására, amiről ő már korábban, bizalmas információként értesült. Ekkor fordult Révaihoz, 1951. április 8-án.

„Az április végén tartandó írókongresszus - a kongresszusok rendje szerint - új vezetőséget választ. Vagy egy hete tudtam meg, hogy az elnöki tisztségről, amelyet közel hat éven át sok nehézség közepette, sikertelenségekkel, eredményekkel vegyesen viseltem, leváltanak.

[...] attól tartok, hogy a váratlanság, amely, a változást jellemzi, esetleg azt eredményezi, hogy a köztudat összefüggést keres majd kultúrfrontunkon megbújt ellenséges elemek leleplezése és felszámolása - és az én »eltávolításom« között.

Huszonhatéves tiszta kommunista múltam és harmincéves tisztességes s eredményes írói munkásságomnak az ilyen látszat - nagyon a kárára volna. És kárára volna pártunknak is. Arra kérem Révai elvtársat, segítsen abban, hogy távozásomnak ne lehessen ilyen látszata. Vagyok igaz szeretettel híve és elvtársa, Gergely Sándor.” Révai kézírásos feljegyzése belső munkatársainak egy nappal későbbi: „Talán adjunk neki kitüntetést?”26

Révai kimenő levele nincs meg, de a válasz igen: „Nagyon köszönöm április 12-i levelét. Kérem, higyje el, nem voltam sose s ma sem vagyok rémlátó, de volt - s van ma is - alapja a segítség-kérésnek. Ezért ismételten köszönöm megnyugtató sorait. Igyekszem továbbra is igazolni a Párt megbecsülését. Mindig is ez volt a célom, életem lényege. Az Írószövetség új vezetőségében, levele értelmében, szerepet vállalok, s ezt tisztességes munkával realizálom s igyekszem - rajtam nem fog múlni - hogy a kongresszuson is, Révai elvtárs kívánsága szerint: »méltóan szerepeljek«. A jó szó sokszor nagyon sokat segít az emberen. Levelét ilyen jó szónak tartom."27

A kommunista önfegyelemnek és csoportfegyelemnek az illegalitásban és emigrációban egyaránt évtizedek óta hatékonyan múködő önfegyelmi gyakorlatai és pártfegyelmi technikái (a szakítás a múlttal, a fordulat, az önkritika, a spicli kereső éberség, az elhajlások szemmel tartása stb.) a káderképzés alapmozzanatai lesznek, Rákosi hatalmi gépezete államosítja az önvizsgálat ezen aszketikus módszereit. ${ }^{28}$

A vezető kegyének megtartásához így Gergely Sándor számára is, aki korábban maga is aktívan bírálatra-önbírálatra szólított fel, szükségessé vált az önkritika gyakorlása.

„Bocsásson meg, hogy újra felkeresem levelemmel. Nemcsak azt akarom megköszönni, hogy életem egyik legnehezebb momentumában a Párt útmutató szavaival segített rajtam...

Az Írószövetség Pártszervezetének a vezetôsége is foglalkozott már az ügyemmel. Cikket kéne írnom róla, önkritikai cikket - és azt szeretném, ha »esetem« tanulságai ne maradjanak egyéni tanulságok, hanem az egész irodalmi közvéleményünk is okuljon belólük.

Most itt vagyok, Visegrádon, az írók Alkotóházában, új regényemen dolgozom, de energiáim nagy részét még mindig közelmúltam elemzése foglalja le. És tépelődésemben 


\section{BeLla KatAlin}

egyre odaérek, hogy nem találok kiutat segítség nélkül. Arra kérem, adjon módot arra, hogy Elvtárstól kaphassam meg önkritikai cikkem irányvonalait - hogy a népi irodalmi egység kérdésének főbb szempontjait jellemezhessem - mint követendő utat, s mint olyanokat, amelyekkel kongresszusi szereplésemmel leginkább összeütközésbe kerültem.

Ne tagadja meg Révai elvtárs ezt a segítséget!

Akár telefonon, akár levélben értesít titkársága - jelzett időre s jelzett helyen ott leszek Elvtársnál. Köszönöm előre is segítségét. Hiszem, hogy átsegít vele egy válságon, amelyet nagyon-nagyon nehéz átélni. Vagyok szeretettel híve és elvtársa, Gergely Sándor." 29

Révai válasza, már a kézhez vett önkritikai írás után, 1951. június 4-én, a teljhatalmú irányítóé: „Kedves Gergely Elvtárs! Elolvastam cikkét. A cikk, persze, ebben a formában nem túlságosan árulja el, hogy maga lelkesedve írta ezt az önkritikát. Nincs megmagyarázva benne komolyan, hogy a kongresszusi beszédével elkövetett komoly politikai hibának mik a gyökerei. A 3. oldalon van erről csupán szó és a magyarázat az, hogy az emigrációs irodalom lebecsülése váltotta ki magából a kongresszusi beszédjének »türelmetlen és helytelen álláspontját«. Ez persze, édes-kevés. Véleményem szerint elemezni kellene bővebben és bátrabban saját álláspontjának hibáit, megmondva, hogy ebben egy bizonyos „rappista”30 szektarianizmus és klikkszellem érvényesült. És hogy a kommunista írók között általában volt (és van is) ilyen »baloldali« klikkszellem és ennek adott maga kifejezést. Ha erre nem mutat rá az önkritika, - az egésznek nincs értelme. Én azt javasolnám, hogy ne féljen megtenni ezt a lépést. Használna saját további múködésének és az egész magyar irodalomnak." ${ }^{1}$

2. A következőkben Németh László példáján lássuk, hogyan kezelte Révai a belső emigrációba visszavonult, a rendszer mellett hitet tenni nem akaró, de a hatalom számára valamennyire mégis megnyerendőnek tekintett alkotókat!

A fordulat éve után Németh László is csak orosz regények fordítójaként lehetett jelen hivatalosan az irodalomban. A fordítói munkát 1949-ben kezdheti meg, Illés Endrének köszönhetően: ,adott [Illés] egy másik fordítást helyette [M. E. SzaltikovScsedrin: A Galavljov család helyett], amelyre, mint gyermekkorom óta velem érő, házasságomban is nyomot hagyó könyvre nem mondhattam nemet: egy évet kaptam a Karenina Anna lefordítására. Karácsonytájt maga a vőm [Szász Imre író, múfordító] állt elő (már nemcsak önálló kereső volt, de protektorom és munkaadóm is; így nôttek akkoriban az ifjú talentumok) - s pont azzal a Sztyepan Kolcsugin-nal kínált meg, amelyet a Révainak lektoráltam."32

Lelkesen vág bele a munkába, de egy idő után a rendkívül feszített tempó, a fordítói brigádszellem, a lektorok kicsinyes kötözködése miatti átdolgozások kényszere kedvét szegi. Ráadásul támadják is fordításai miatt, nem akarják megjelentetni se a Sztyepan Kolcsugint, se az Anna Kareninát. ${ }^{33}$

Közben elhangzik Horváth Márton beszéde 1950-ben, ahol nyilvánosan azt mondja Németh Lászlóról, hogy „Az ellenséges írókra és irodalomra Németh László a legjobb 


\section{„KÉREM, NE LEGYEN TÚL ÉRZÉKENY.” IRODALOMPOLITIKA ÉS KÖNYVKIADÁS RÉVAI JÓZSEF MINISZTERSÉGE IDEJÉN}

példa. Németh László minden jel szerint jelentékenyebb ellenség, mint amilyen jelentékeny író (...) kevés ember volt, aki annyi kárt tett az elmúlt emberöltő alatt az ifjúság nevelésében, mint ő." ${ }^{34}$

Némethet nemzedéktársai közül szoros kapocs füzte Illyés Gyulához, a fontos irodalompolitikai lépései előtt is konzultált vele. ${ }^{35} \mathrm{E}$ durva támadás után is ő az, aki, bár igencsak kurtán-furcsán, de nem hagyja magára: „Pestről semmi hang; csak Illyés Gyulától kaptam egy különös rövidke levelet. Olyasmi volt benne, hogy amit Horváth Márton mondott rólam: irodalmi bírálat volt, amelynek a politikai következményeitől nem kell tartanom. Bennem kétféle érzést váltott ki ez a levél. Volt valami ügyetlenség a fogalmazásban, ami nem vallott Gyulára, a cáfolat úgy volt odavetve, hogy szinte állítás lett belőle: igen, ez politikai szétzúzás volt, mi is aggódva várjuk, mi történik utána, de azért igyekszünk megnyugtatni egy levélke erejéig. Azonban épp ez az ügyetlenség mégiscsak jólesett - '(s egyáltalán, hogy írni mertek, s biztatják, alkalmasint a postájában is ellenőrzöttet, ez mégis csak jólesett.) A levél titka évek múlva fejtődött meg, Illyéséknél. Arról volt szó, hogy Flóra milyen jól utánozza Gyula kézírását. Még leveleket is ír a nevében, főleg ha fiatal költőket kell biztatniuk. - De velem még nem levelezett Gyula képében? - kérdeztem gyanút fogva. Nevetés volt a válasz." ${ }^{36}$

A fordítások terén végül is Veres Péter közbenjárása hozza el a fordulatot. Az Anna Karenina és Zakrutykin műve, Az úszó falu elhozza a műfordítói elismerést számára, József Attila-díjat is kap.

„Egyszer csak egy vastag borítékos levelet hoznak be, a Népmúvelési Minisztérium pecsétjével. $\mathrm{Na}$, becitálnak megint, gondoltam. Kinyitom: a miniszterhelyettes értesít, hogy a Karenina Anna és a Zakrutykin Az úszó falu-jának a fordításáért a József Attila-díj első osztályával tüntetnek ki. Elképedve forgatom a levelet. A feleségem se tudja, megijedjen vagy örüljön-e. Nekem régi fogadalmam, még a baumgartenes időkből, hogy dijat soha nem fogok elfogadni. Ezt azonban lehetetlen visszautasítani. Lázasan megyek át a díjkiosztásra. Ott Darvas a kiosztást követő kávézgatás alatt állandóan a mi asztalunknál ül. A feleségemet külön is megkéri, hogy ha valami kívánságunk van - tudja, milyen büszke vagyok -, csak forduljon a hírem nélkül is hozzá. Itt valami csoda történt - érezzük -, de hogy mi, nem tudom megfejteni. Éveken át Révai József javára írtam ezt is, s csak a legutóbbi időben kaptam meg a valódi megfejtést."'37

Hogy a díj egész pontosan Rákosi Mátyásnak volt köszönhető (akinek feltűnt, ,,milyen szeretettel” van fordítva Az úszó falu), ${ }^{38}$ azt máshol mégiscsak megírja: „Az, hogy a Karenina Anna Révai Józsefből néhány elismerő szót váltott ki, s hogy Zakrutykinfordításom olvasója, az akkori pártfőtitkár, a fordító s a börtönben olvasott Tanú-számok közt felfedezte az összefüggést (a legváratlanabb égből egy József Attila-díjat hullatva elém): biztosította, hogy csömörig kapjam a fordítást." ${ }^{39}$

Mindez ébren tartja Révai érdeklődését is, és lassan felmerül a remény, hogy saját mú is megjelenhet újra. ${ }^{40}$ Németh László maga írja, hogy „1952 tavaszán a főideológus: Révai József (akinek kétszeresen is hálával tartozom: 1945-ben ő mentett meg ellenségeim, írótársaim kezéből, 1949 után pedig ő adott kenyeret a fordításban), midőn egyik 


\section{BELLA KATALIN}

fordításomat megküldtem neki, válaszlevelében azt kérdezte: nem volna-e kedvem eredetit is írni?”41 Révai levele a következő: „Igen tisztelt uram! hálás köszönet a Kolcsugin és az Anna Karenina kitűnő fordításért. Nem volna kedve a fordításon kívül valami egyebet is csinálni? Dolgozik-e a Budai Nagy Antal regényen?’42

Ennek eredményeképpen Németh László hozzákezdhetett a Galilei megírásához, amely már az új, Darvas-vezette művelődéspolitika idején kerül az irodalmi élet irányítói elé.

3. Illyés Gyula ambivalens kezelése újabb adalékkal szolgál Révai irányítási módszereihez. Illyés Gyulát kivételes - és ennek folytán kivételezett - viszony füzte az ötvenes évek, a személyi kultusz politikai hatalmasságaihoz. Esetében a kiemelkedő múvészi tehetség s az iránta megnyilatkozó politikai sznobizmus, a progresszív szellemiségű magyar irodalomban játszott kiemelkedő szerep és ennek folytán szerzett országos tekintély mellett még az a különleges körülmény is közrejátszott, hogy a hajdani forradalmár költő és a magyar kommunista mozgalom első nemzedékéhez tartozó vezetők életrajza bizonyos pontokon már évtizedekkel korábban: a húszas évek kezdetétől össze-összekapcsolódott. ${ }^{43}$ Rákosiéknak tehát az volt az érdekük, hogy kiálljanak a Nemzeti Parasztpárt vezető személyiségei mellett - mindaddig, amíg szükségük van rájuk, így - a nyilvánosság előtt - 1945-ben és 1946-ban is „megvédték” Illyés Gyulát a rágalmazó támadásoktól. ${ }^{44} \mathrm{~S}$ bár 1948-ban Illyés az elsők között kapta meg a Kossuth-díjat, ekkor még vitathatatlanul rangos társaságban, Déry Tiborral, Füst Milánnal, Lukács Györgygyel és Nagy Lajossal együtt, a fordulat éve után megfagyott körülötte a levegő. Amikor 1950 februárjában a Magyar Dolgozók Pártjának Politikai Akadémiáján Horváth Márton hatalmas terjedelmú előadást tartott, abban Németh Lászlót nevezte meg, mint az ellenséges írók legszemléletesebb példáját. Majd felsorolta a demokratikus rendszer írói táborának tizennyolc képviselőjét, hozzátéve, hogy „Ide lehet sorolni - bár nála eddig csak az ingadozás volt állandó - Illyés Gyulát." ${ }^{45}$

Szintén a nagy nyilvánosság előtt zajló tetemrehívás, amikor a Magyar írók I. Kongresszusán a referátumok után elsők között kapott szót egy ifjú akarnok, aki kérdőre vonta Illyés Gyulát hallgatása miatt, az „egész dolgozó nép nevében”, közölve, hogy csalódott az alkotóban. ${ }^{46}$ Illyésnek sikerül elegánsan elhárítani a hűségnyilatkozatot ${ }^{47}$, bár Révai később kijelenti, hogy Az építők című vers nem oldotta meg az „Illyés-problémát”, mert az író továbbra is nemcsak a dolgozó néphez kötődik, de „bizonyos barátokhoz is, akik „a szocializmust építő népnek hátat fordítanak.” Révai azt követelte tehát Illyéstől, hogy hozza magával a barátait (Szabó Lőrinc, akire ez elsősorban vonatkozott és aki jelen volt a kongresszuson, fel is tette a kérdést: „Hozza magával a barátait? [...] De hova?”). ${ }^{48}$

Paradox módon az irodalompolitika fokozódó nyomása, a szocialista realizmus zsdanovi tételeinek számonkérése mellett a hatalom mégis, továbbra is igyekszik azt a látszatot kelteni, hogy a kor nagy írója mellette áll. Megkapja „,a legnagyobb élő magyar költő" - általa soha nem óhajtott - címet, ötvenedik születésnapjára a Szépirodalmi Kiadó tízezer példányban megjelenteti válogatott verseinek gyújteményét, újonnan írt drámái színpadot kapnak, nyomtatásban is megjelennek, s 1953-ban másodszor tüntetik ki Kossuth-dijjal. ${ }^{49}$ 
Ugyanez a kettősség a színfalak mögött is érvényesül Illyés és a pártvezetők viszonyában.

Illyés Naplójában olvashatjuk: „Rákosi hozzám, társaságban tréfásan előzően: - Nem akarod kompromittálni magad velünk! - Épp eleget vagyok már kompromittálva. Előbb Vas kétszer is Horváthnak, mit mondott $2 \times$ is a londoni rádió rólam. [...] Horváth M.: azt a te Londonba került régi polgári ellenfeleid csinálják! A régi Szép Szó. Újabb támadás is volt London részérôl. Rákosi előbb: - Látod: mindkét oldalról miket kapsz! - Hozzászoktam, így marad meg az ember a... - nem tudom befejezni, hogy a nyeregben, a középúton?"50

A nyereg vagy középút megtartása azonban nehéz: „Egy rendezvényen Tyihonov [Nyikolaj Szemjonovics Tyihonov szovjet író és költő, akit hivatalosan Illés Béla látott vendégül több magyar író társaságában 1950-ben ${ }^{51}$ ] első szava az volt, hol van Illyés Gyula? (!) [...] Kijövet Illés bemutat Ty.-nak. - A legnagyobb magyar költő. Révai (ő volt állandóan Tyihonovval) szellemesen hozzáteszi: - Írt egy jó könyvet a Szovjetunióról; de aztán ő maga sem hitte el!" 52

Illyés azonban mindkét oldalról nyomás alatt van, hiszen nemcsak azt kell kivédenie, hogy túlságosan exponálódjon a hatalom mellett, hanem diszkvalifikálódni sem szeretne, viszont kivételezett pozíciója miatt gyakran kérik közbenjárásra azok, akik a pálya szélére szorultak, a fordulat éve előtti irodalmi élet méltatlanul kiiktatott szereplői.

Az még kényesebbé teszi a helyzetet, hogy még 1945 után Rákosiék (természetesen, mert meg akarták nyerni a maguk érdekeinek) Illyés Gyulának azokat a kívánságait-követeléseit teljesítették is, amelyekkel meggyanúsított írótársainak sorsát akarta rendezni ('́gy rendeződhetett, ha nehezen is, Szabó Lőrinc és Németh László 1945 utáni sorsa, így sikerült elérni, hogy a szépíróknak ne kelljen igazolóbizottság elé állniuk) ${ }^{53}$, tehát többen úgy érezhették, hogy Illyés sikeresen segíthet is rajtuk, ha ő emel szót, tôle bármit elfogadnak.

Basch Lóránt esetében Illyés valóban meg is próbált közbenjárni.

A Baumgarten Alapítvány felszámolása már 1948-tól terítéken volt. Révai kizárólag a nagy tiszteletnek örvendő, 77 éves, ekkor már beteg Schöpflin Aladárra való tekintettel nem intézkedett. ${ }^{54}$ A Baumgarten-díj megszüntetése után az alapítvány kurátora, Basch Lóránt igyekezett menteni a menthetőt. ${ }^{55}$ Javasolta tehát az alapítvány fenntartását könyvtár létesítése céljából, amely egyrészt Baumgarten emlékét lett volna hivatott ápolni, másrészt fontos irodalomtörténeti funkciót töltött volna be a Nyugatkorszak könyv- és kéziratanyagának összegyújtésével. A javaslatot azonban az Irodalmi főosztály nem fogadta el.

Az első érv az, hogy nem tartották méltónak Baumgarten Ferencet arra, hogy nevét megörökítsék, nyilvánvalóan azért, mert a gazdag ügyvéd magánalapítványának további fenntartása összeférhetetlen a rendszer alapelveivel.

A második ok az, hogy a József Attila-díj létrehozásakor már megszületett a határozat a Baumgarten-alapítvány megszüntetéséről, a tényleges feloszlatás elhúzódása annak köszönhető, hogy „Basch Lóránt a legkülönbözőbb trükkökkel kitért a nyílt állás- 


\section{BELLA KATALIN}

foglalás elől. Azóta mozgósítani próbálta Devecserit és Gellért Oszkárt, kevés sikerrel: és a jelek szerint Illyés Gyulát, nagyobb sikerrel." ${ }^{56}$

Valóban, Illyés Gyula írt közbenjáró levelet Basch érdekében: „Kedves Barátom, Babits Mihály részben rám hagyta a Baumgarten-alapítvány gondját; e minőségemben kérlek, hogy - noha az alapítvány közvetlen szerepe megszűnt - vizsgáld meg Basch Lóránt előterjesztését. Nyilván te is ismered Basch Lóránt érdemeit a baloldali irodalom segítése körül. Ennek én gyakran tanúja voltam. Méltatlanságnak érezném, ha most, a küzdelmes évek után nem történnék ellátásáról megnyugtató gondoskodás. Őszinte nagyrabecsüléssel köszönt híved, Illyés Gyula." ${ }^{57}$

Pap Károly kommunista meggyőződésű, de a vallásos érzelmekkel, zsidó hittel és Krisztus alakjával is sokat foglalkozó kiváló író posztumusz kiadása ügyében nem járt közben, azonban hiába óvatos, ez is visszajut Révaihoz, ugyanis az özvegy megírja Illyés tétlenségét, mikor kéri Pap Károly műveinek kiadását. Illetve a kiadás előbbre hozását, mivel a terv szerint csak 1954-ben jelenhet meg tőle egy kis kötet, de ez sem biztos. Pedig, írja az özvegy, Móricz a világirodalom legnagyobb novellistái közé sorolta Pap Károlyt, és Osváth is megírta öngyilkossága előtt egy órával végrendeletű levelét Gellért Oszkárnak, melyben Pap Károlyt és Illyés Gyulát ajánlotta - „Illyés Gyulát, egykori legjobb barátját, aki most rejtélyesen hallgat." 58

Pap Károlyné közvetlen Révainak címzett, Illyés alkalmazkodását és taktikázását sugalló levelét indokolhatja egyfelől, hogy ő maga igazi fanatikus, ha férje munkásságáról van szó, ahogy ezt Németh László is megfogalmazta még 1933-ban: „Amíg én Pap Károllyal fújtam a sűrű cigarettafüstbe drámákat, regényeket, a feleségem Pap Károlynét hallgatta, ami nem volt kis áldozat. Ez az asszony, alig egy év alatt, az egész irodalmi világ borzalmává tudott válni. Mint férje zsenialitásának az ügynöke tört be mindenhová. Olvasták Kari novelláját a Nyugat-ban, volt az első kérdése, s jaj annak, aki a világirodalomban különb novellát is olvasott. Még férje előző írásaira is féltékeny volt, mert mindig az utolsónak kellett a legtökéletesebbnek lenni." ${ }^{59}$ Másfelől a sérelmező szavak oka lehet, hogy valóban, Illyés maga is kebelbarátjának tartotta Pap Károlyt, régi barátságukat már az 1929-ben íródott A Tiszánál című versben is megörökítette. ${ }^{60}$

Hogy milyen kényszerhelyzetben lehetett Illyés saját megszólalásai gondos mérlegelésére, azt pedig jól érzékelteti Devecseri Gábor 1952-ben a minisztériumba küldött bizalmas levele a Basch-iratok között:

„A Tamás Aladár előadását követő vita során második felszólalásom elején Illyés Gyula műveivel kapcsolatban azt mondottam, hogy nagyrabecsülöm és tisztelem Illyés művei közül azokat, amelyekből mindenki csak azt tanulhatja, hogy ne értsen egyet Ilylyés mostani, levélben elküldött felszólalásával. - A gyorsíró ezt pontosan megfordítva jegyezte föl, a nagyrabecsülést Illyésnek azokra az »érveire« vonatkoztatta, »amelyekkel többen nem értenek egyet«."

Persze a legjobban maga az érintett látta visszás helyzetét, a görénynek, azaz az irodalompolitikának a hattyú, azaz saját költészete nyaka köré fonódását, ${ }^{62}$ ahogy azt Naplójában meg is fogalmazta: 


\section{„KÉREM, NE LEGYEN TÚL ÉRZÉKENY.” IRODALOMPOLITIKA ÉS KÖNYVKIADÁS RÉVAI JÓZSEF MINISZTERSÉGE IDEJÉN}

„Egy fogadáson, a gazdagon megterített asztalnál Révai mellett ültem. Kedélyesen poharaztunk, de élesen vitatkoztunk. Megállt a hátunk mögött Illés Béla. Neki nyilván más asztalnál volt helye, egy alacsonyabb rangfokozatúnál, s így itt nem ülhetett le. Mihelyt megláttam, abbahagytam a beszédet; feléje fordultam, mondja ô a magáét. Révai azonban befejezte a kettőnk társalgását, s csak aztán vetett egy kelletlen tekintetet Illés felé!

- Ha nem zavarom, arról kérném Révai elvtárs véleményét... - és belekezdett valami cikk megírásának vagy meg nem írásának ismertetésébe. - Zavar - mondta Révai a mindkettőnknél idősebb Illésnek. S ez bólintott, s elment. Elpirultam, hallgattam. Együttesen akár a halálomat is megrendeznék, ha arra kapnak irányítást. S személyileg külön-külön közelebb vannak hozzám, mint egymáshoz." ${ }^{63}$

4. A Révaival közvetlenül kapcsolatba kerülő alkotók következő köre a származás vagy előélet szempontjából megfelelő közepes vagy szerény színvonalon alkotó íróké.

Arra, hogy velük miképpen bántak, a rengeteg esetből álljon itt egy hosszabb és egy rövidebb példa. Az első Sarkadi Kálmáné. A Révai titkárságának szóló feljegyzés szerint Sarkadi elküldte a minisztériumba készülő regényének egy részletét a rá vonatkozó lektori véleményekkel együtt. Leveléből az is kiderült, hogy 1919-ben vöröskatonának állt. A „Horthy-terror” idején kezdetben letartóztatásban volt, majd megszökött és egészen az 1936-os amnesztia-rendeletig az országban bujkált, napszámosként és alkalmi munkásként dolgozott. 1940 óta rokkant, 1949 óta rokkantjáradéka az egyetlen bevétele, a pártnak 1946 óta tagja.

„Hosszabb ideje regényt, illetve önéletrajzi emlékeket ír, azonban írásairól az öszszes lektori vélemények (Írószövetségtől, Munkásmozgalmi Intézettől, Szépirodalmi Kiadótól) negatív értékelést tartalmaznak. A »Előre 1918-19« c. regényének egy részletét a főosztály is megnézte és kiadásra alkalmatlannak találta. Véleményünket közöltük Sarkadi elvtárssal és azt a tanácsot adtuk neki, hogy tekintettel Sándor Kálmánnal fennálló személyes ismeretségére (aki szintén irt már 1918-1919-es témáról) forduljon hozzá és kérje meg arra, hogy segítsen neki kéziratainak kijavításában, illetve új írásainak új elkészítésében." ${ }^{64}$

Sándor Kálmánt hivatalosan is Sarkadi mellé rendelik ${ }^{65}$, ezen felül pedig megállapítják, hogy tekintettel 75\%-os rokkantságára, portásként is elhelyezhető lenne valamelyik vállalatnál.

A másik ügy a következő: Dobi István, aki ekkor a minisztertanács elnöke, kéri, hogy vegyenek fel valakit a Kis Újsághoz. Révai elrendeli, hogy „Dobi kérését teljesíteni kell, ha ez a Simonné nem apagyilkos”. Így természetesen felveszik a jelöltet, „,szerencsére nem kellett elküldeni senkit", áll az eset lezárásáról szóló jelentésben. ${ }^{66}$

5. Révai működésekor értelemszerűen nemcsak a kortárs írókkal, hanem a hajdaniakkal is foglalkozott.

Közvetlen irányítására nem egy betiltás vagy kiiktatás példáját hozzuk, hanem egy klasszikus költő, Ady hagyatékának kezelését. 


\section{BELLA KATALiN}

Ady a fordulat éve után egyik kulcsfontosságú figurájává válik az ideológiai irodalomértelmezésnek, a hatalom eszmei legitimálása az Ady-életmú „feladata” is. Ilyen, a politikai ideológiáktól mentes esztétikum zártságát megtörő publikációk először 1947ben jelennek meg, például az Irodalomtörténet folyóirat hasábjain. ${ }^{67}$ Az alaphangot az új értelmezésben Révai József és Lukács György még Moszkvában, esztendőkkel korábban írt, a „forradalmár Adyt” abszolutizáló munkái adták meg. ${ }^{68}$

A forradalmár Ady azért Lukácsnál és Révainál is ellentmondásos, történelmi határhelyzetben lévő figura, Révai az MDP 1951. februári második kongresszusán elmondott beszédében el is marasztalja József Attilával együtt. Ők - Petőfivel ellentétben nem voltak eléggé összeforrva koruk forradalmi népmozgalmával. A pontos kifejezés, amit Révai alkalmaz rá, a következő lesz: „Petőfi: tézis, Ady: antitézis, József Attila: szintézis”. Ady tehát Révainál „forradalom nélküli forradalmár” lesz, aki ugyan kortársai közül a legmesszebbre jutott a politikai tisztánlátásban, de mégis, környezetének visszahúzó, torzító hatásai valóban nyomot hagytak rajta, nem tudott kitörni hanyatló korszakából. Erre az okfejtésre azért van szükség, mert Lukács és Révai nehezen boldogulnak azzal, hogy megmagyarázzák Ady „kétlelkűségét” a forradalommal kapcsolatban, azt például, hogy Ady csodálja ugyan Petőfi forradalmi tüzét, de egyúttal illuzórikusnak is tartja azt, vagy, hogy kezdjenek valamit az Ady-költészet individualizmusával, halál-romantikájával, dekadens, franciás szimbolizmusával, szerelem-képével, kuruc-kultuszos nemzetfelfogásával és istenes verseivel. ${ }^{69}$

Ezt az Ady-képet először csak Sztálin halála után töri meg egy-két merészebb észrevétel, például az 1952/53-as tanévre megjelent gimnáziumi tankönyvben Makay Gusztáv diákjaira hivatkozva kifogásolta, hogy Ady bemutatása, mely Révai József tanulmányát követi, alig foglalkozik a „szenvedélyes polgári életvágyat” kifejező költeményekkel vagy a halál-versekkel. ${ }^{70}$

Mivel Ady szerepe ilyen kiemelkedően fontos ideológiai szempontból, ennek megfelelően veszi kézbe Révai hagyatékának ügyét is.

Az ügy 1950 végén kezdődik, amikor az örökös, Ady Lajosné felajánlja a Magyar Tudományos Akadémiának megvételre a tulajdonában lévő Ady-dokumentumokat. Nagy Péter irodalomtörténész, aki ekkor az MTA titkári hivatalában dolgozik, Losonczy Gézával mint népművelési államtitkárral tárgyal. „Az anyag megszerzése egyre égetőbb, mivel félő, hogy Ady Lajosné halála után avatatlan kezekbe kerülve, sokkal nagyobb öszszeg ellenében válnak majd csak megszerezhetőkké, ha ugyan végleg el nem kallódik."'71 A hagyaték tartalmáról Földessy Gyula irodalomtörténész, Ady-szakértő készít jelentést, amelyet Losonczy juttat el Révainak. A hagyaték tartalma igen értékes (többek közt az Elbocsátó szép üzenet kézirata, valamint több száz levél Ady barátaitól, tisztelőitôl, szerelmeitől). Ady Lajosné cserébe az újonnan megjelenő Ady-múvek bruttó jövedelme 15\%-ának egy hatodát kéri, amely összeget még az Ady-család és Boncza Berta pereskedése végén ítéltek meg neki, valamint ezen felül még 5000 forint segélyt. A feltételeket Földessy elfogadásra javasolja, Ady Lajosné megérdemelné az állami támogatást, nemcsak súlyos egészségügyi problémái miatt, hanem mert „származása, neveltetése ellenére meg tudta érteni az idők szavát."72 


\section{„KÉREM, NE LEGYEN TÚL ÉRZÉKENY.” IRODALOMPOLITIKA ÉS KÖNYVKIADÁS RÉVAI JÓZSEF MINISZTERSÉGE IDEJÉN}

Révai első ajánlata 7-8 000 forint, de évjáradék nélkül, amit Ady Lajosné nem fogad el, ha le kell mondania az évjáradékról, akkor 50000 forintot kér a gyújteményért. Révai hajlandó engedni, 35-40 000 forintot egy összegben, vagy havi 400 forintot adna a dokumentumokért. Márciusra aztán elkészül a Révai által kért szakértői jelentés, amely megállapítja, hogy a minimális érték 25200 Ft, de felhívja a figyelmet arra is, hogy Ady Lajosné korábban már igen jelentős kéziratos és ereklyeanyagot, bútorokat, ékszereket ajándékozott a Magyar Nemzeti Múzeum Széchényi Könyvtárának. Így Nagy Péter, Földessy Gyula és Kerek Gábor, aki ekkor könyvkiadói osztályvezető a Népművelési Minisztériumban, 30000 forintot ajánl fel, de ezt az örökös még mindig nem tartja méltó ellenszolgáltatásnak. Révai újabb javaslata a következő: „Még egy utolsó kísérletet kellene tenni: 10-15 000 frt. egy összegben és 400 frt. havonta. [...] Ha ebbe sem megy bele, meg kell nézni, van-e törvényes lehetőség az anyag állami igénybevételére kártérítés mellett? A dolog anyagi része szerintem az Akadémiára, és nem a Népműv. Min-ra tartozik, hiszen Ady-kutatást az Akadémia folytat.”

Közben Ady Lajosné ismeretlen okokból változtat az álláspontján, teljesen lemond az évjáradékról, így végül 45000 forintért a Magyar Tudományos Akadémia megvásárolja Ady hagyatékát. ${ }^{73}$

Megfelelő összegzés arra, hogy Révai mint „kultúrdiktátor”74 milyen légkört teremtett, az 1951-es Kossuth-díj kiosztása utáni, az irodalmi mezőnyt pillanatképként rögzítő hangulatjelentés.

„A Kossuth-díj kiosztást követő napon a Magyar Írók Szövetségében rendkívüli taggyưlés volt, amelyre a kongresszusi napirendre való tekintettel több pártonkívülit, vagy nem az alapszervhez tartozókat is meghívott a vezetőség. Magán a taggyúlésen nem hangzott el még hozzászólás formájában sem állásfoglalás a Kossuth-díjjal kapcsolatban, csak a taggyúlést megelőző időben és annak szünetében lehetett tapasztalni, hogy a dijkiosztás nagy port vert fel.

Elsősorban az önjelöltek voltak, akik hangot adtak az elégedetlenségüknek. Szinetár György, Karinthy Ferenc (akire fogadásokat is kötöttek a Szépirodalmi Könyvkiadónál), Sándor András, Sándor Kálmán, Rideg Sándor és Szüdi György nyilatkozgattak, vagy élcelődtek egymással. Érdekes az is, hogy ki milyen alapon jelölte magát, miért számított a díjra. [...]

Sándor András azon az alapon várt Kossuth-dijat, hogy Révai elvtárs megemlítette őt a kongresszusi referátumában és ő ebből azt következtette, hogy ez olyan jelentőségű, hogy ezután más nem is jöhet. Emellett úgy értesült, hogy Rákosi elvtárs is jónak találta riportkönyvét, de a DISZ is rehabilitálta. Nem kis szerepet játszott reményeiben, hogy a Szépirodalmi Könyvkiadónál Simó fogadásokat kötött az ő Kossuth-díjára és Losonczy is olyan kijelentést tett, amelyből arra következtetett, hogy már meg is szavazták neki.

Sándor Kálmán ugyancsak a kongresszusi beszéd alapján számított a Kossuthdíjra, de igen sokan közölték vele írótársai közül is, hogy biztos tudomásuk van arról, hogy kap. Pl. Déry volt az egyik froclizó és Aczél Tamás, Molnár Miklós is arra tippeltek, hogy kap. 


\section{BELLA KATALIN}

Karinthy kiindulási pontját nem sikerült megismernem, de szemtanúja voltam annak, hogy milyen aljasul froclizta őt Lukácsy Sándor, aki megfogva Karinthy gomblyukát nevetve mondta »jó író, jó szövet, csak innen hiányzik valami, nem baj Cini, te még ettôl jó író lehetsz«. Rideg Sándor Kossuth-díja bent élt a köztudatban. Hogy ki dobta be, nem tudom, de, hogy nagy ügyet a volt Népszavás írók és költők frakciója, vagy enyhébben szólva tömörülése csinált ebből, az Földeák aznapi kiborulásából is világosan kitűnt, (errôl külön, részletesebben, mert ez több dolgot is tartalmaz).

Szüdi maga nem is merte volna remélni a díjat, ha Földeák, nem veti fel olyan élesen a kérdést. Az Írószövetségben általában nem értettek egyet a Kossuth-díjjal. Igazságtalannak tartották Hámost, sokan Juhászt, de Szabó Pált is.

Simó pl. a Szépirodalmi Könyvkiadó bizalmas berkeiben úgy nyilatkozott, hogy Déry Tibornak és Rideg Sándornak feltétlenül kellett volna kapnia, sokkal inkább mint Hámosnak és Háynak. Grandpierre Emil ezt azzal toldotta meg, hogy a színházat sokkal jobban megbecsülik, mint az irodalmat. Ez a kiosztás a sematizmus tovább istápolása felé vezet, mert a díjazott művek nem múvésziek, csak hasznosak politikailag. Ezzel Simó és Vas István is egyetértettek." 75

\section{Irodalom és jegyzetek}

${ }^{1}$ SÁRKÖZI Mátyás: A bizarr évei: élet és irodalom Rákosi Mátyás alatt. Budapest, Kortárs, 2009. 57. p.

${ }^{2}$ VALUCH Tibor: Magyarország társadalomtörténete a XX. században. Budapest, Osiris, 2005. 141. p.

${ }^{3}$ VALUCH Tibor 2005. i. m. 149-150. p.

${ }^{4}$ RAINER M. János: A felügyelt mozgástér: tanulmányok a szovjet típusú rendszer hazai történetéből. Budapest, Akadémiai Kiadó, 2011. 28. p.

${ }^{5}$ KALMÁR Melinda: Történelmi galaxisok vonzásában: Magyarország és a szovjetrendszer 1945-1990. Budapest, Osiris, 2014. 56. p.

${ }^{6}$ STANDEISKY Éva: Az írók és a hatalom. Budapest, 1956-os Intézet, 1996. 19. p.

7 BOLVÁRI-TAKÁCS Gábor: Révai József és a Népművelési Minisztérium létrehozása. = Zempléni múzsa, 2. évf. 4. (8.) sz. 2002. 14-26. p. Forrás: http://www.zemplenimuzsa.[-] hu/02_4/bolv.htm [2016. január 9.]

${ }^{8}$ DOMOKOS Mátyás: Leletmentés: könyvek sorsa a „nemlétező” cenzúra korában, 1948-1989. Budapest, Osiris, 1996. 11. p.

9 ACZÉL Tamás - MÉRAY Tibor: Tisztító vihar. München, Griff, 1982. Forrás: http://dia.[-] jadox.pim.hu/jetspeed / displayXhtml?offset=1\&origOffset=-1\&docId=613\&secId[-] $=57374 \& q d c I d=3 \&$ libraryId=-1\&filter $=\mathrm{M} \% \mathrm{C3} \%$ A 9 ray + Tibor\&limit=1000\&pageSet $=1$ [2016. január 9.]

${ }^{10}$ STANDEISKY Éva: A kommunista polgárellenesség. = Budapesti Negyed, 8. évf. 2. sz. 1995. 209-222. p. Forrás: http://epa.oszk.hu/00000/00003/00007/standeis.htm [2016. január 10.]

${ }^{11}$ Magyar Nemzeti Levéltár (továbbiakban: MNL) XIX-I-3-e 2. dob. 1320. tétel.

${ }^{12}$ REICHERT Gábor: Mintha négykezest zongoráznánk. = Holmi, 22. évf. 6. sz. 2010. 744-759. p. Forrás: http://www.holmi.org/2010/06/reichert-gabor-\%E2\%80\%9Emintha-negy[-] kezest-zongoraznank\%E2\%80\%9D [2016. január 10.] 


\section{„KÉREM, NE LEGYEN TÚL ÉRZÉKENY.” IRODALOMPOLITIKA ÉS KÖNYVKIADÁS \\ RÉVAI JÓZSEF MINISZTERSÉGE IDEJÉN}

${ }^{13}$ MNL XIX-I-3-e 3. dob. 1478. tétel.

${ }^{14}$ REICHERT Gábor: Önkritika-forgatókönyv a Felelet-vita után. = Irodalomtörténet, 94. évf. 2. sz. 2013. 265-282. p. Forrás: http://epa.oszk.hu/02500/02518/00340/pdf/EPA02518[-] _irodalomtortenet_2013_02_265-282.pdf [2016. január 10.]

${ }^{15}$ STANDEISKY 1995. i. m.

${ }^{16}$ MNL XIX-I-3-e 3. dob. 2715. tétel.

${ }^{17}$ BOTKA Ferenc: Déry Tibor levelezése: 1951-1955. Budapest, Balassi, Petőfi Irodalmi Múzeum, 2009. 35. p.

${ }^{18}$ STANDEISKY Éva: A magyar irodalmi élet szovjetizálása 1949 és 1951 között. = Múltunk, 49. évf. 1. sz. 2004. 48-82. p. [2016. január 25.]

${ }^{19}$ SÁRKÖZI Mátyás 2009. i. m. 105-106. p.

${ }^{20}$ REICHERT 2013. i. m. Forrás: http://epa.oszk.hu/02500/02518/00340/pdf/EPA02518_[-] irodalomtortenet_2013_02_265-282.pdf [2016. január 10.]

${ }^{21}$ BOTKA Ferenc 2009. i. m. 128. p.

${ }^{22}$ MNL XIX-I-3-e 6. dob. 1309. tétel.

${ }^{23}$ STANDEISKY Éva 1996. i. m. 19. p.

${ }^{24}$ VASY Géza: A Magyar Írószövetség rövid története. Forrás: http://www.iroszovetseg.hu/[-] wp-content/uploads/2012/09/MI_tortenete.pdf [2016. január 15.]

${ }^{25}$ STANDEISKY Éva 2004. i. m.

${ }^{26}$ MNL XIX-I-3-e 3. dob. 1611. tétel.

${ }^{27}$ MNL i. m. 1673. tétel.

${ }^{28}$ SZOLLÁTH Dávid: A kommunista aszketizmus esztétikája. PhD-értekezés. Pécs, 2008. 31. p. Forrás: http://irodalomdoktori.btk.pte.hu/files/tiny_mce/szollath_doktori.pdf [2016. január 15.]

${ }^{29}$ MNL i. m. 1746. tétel.

${ }^{30}$ A túlzott baloldaliság, a kommunista gőg, az együttmúködésre képtelenség szinonimája, a Rosszijszkaja asszociacija proletarszkih piszatyelej (Proletárírók Oroszországi Egyesülete) rövidítéséből ered, melynek történetéről lsd. SVECOVA, Ljubov: Proletár írószervezetek 1920-1930. = Helikon, 12. évf. 1-2. sz. 1966. 5-17. p. Forrás: http://real-j.mtak.hu/[-] 1194/1/HELIKON_1966.pdf [2016. január 15.]

${ }^{31}$ MNL i. m. 1888. tétel.

${ }^{32}$ NÉMETH László: Magam helyett. Budapest, Püski, 2002. Forrás: http://dia.jadox.pim.hu/ [-] jetspeed $/$ displayXhtml?offset $=1 \&$ origOffset $=-1 \&$ docId $=7501 \&$ secId $=810723 \&$ limit [=50\&pageSet $=1$ [2016. január 25.]

${ }^{33}$ FÜZI László: Alkat és mú. Pozsony, Kalligram, 2001. 449. p.

${ }^{34}$ VASY Géza: Hol zsarnokság van. Forrás: http://www.tankonyvtar.hu/hu/tartalom/tkt/[-] holzsarnoksag-van/ch02.html [2016. január 16.]

35 TÜSKÉS Tibor: A levélíró Németh László. = Tiszatáj, 55. évf. 4. sz. 2001. Forrás: http://[-] epa.oszk.hu/00700/00713/00116/pdf/tiszataj_EPA00713_2001_04_080-090.pdf [2016. január 25.]

${ }^{36}$ NÉMETH László 2002. i. m.

${ }^{37}$ NÉMETH László 2002. i. m.

${ }^{38}$ PÜNKÖSTI Árpád: Rákosi bukása, száműzetése és halála. Budapest, Európa, 2001. 642 p. Forrás: http://mek.oszk.hu/05300/05385/05385.htm [2016. január 25.] 


\section{BELLA KATALIN}

${ }^{39}$ NÉMETH László: A kísérletező ember. Budapest, Magvető, 1973. 768 p. Forrás: http:/ /dia.[-] jadox.pim.hu/jetspeed/displayXhtml?offset=1\&origOffset=-1\&docId=212\&secId=[-] 19704\&limit=10\&pageSet=1 [2016. január 25.]

${ }^{40}$ FÜZI László 2001. i. m. 452. p.

${ }^{41}$ NÉMETH László: A felelősség szorításában. Budapest, Püski, 2001. 33. p. Forrás: http:/ [-] dia.jadox.pim.hu/jetspeed/displayXhtml?offset=1\&origOffset=-1\&docId=7898\&secId[-] $=830017 \&$ limit $=50 \&$ pageSet $=1$ [2016. január 25.]

${ }^{42}$ MNL XIX-I-3-e 4. dob. 484. tétel.

${ }^{43}$ DOMOKOS Mátyás: Adósságlevél: esszék, tanulmányok Illyés Gyuláról. Budapest, Kortárs, 1998. 104. p.

${ }^{44}$ VASY Géza: Haza a magasban. Budapest, Nap Kiadó, 2010. 32. p.

${ }^{45}$ VASY Géza: Illyés Gyula. Budapest, Elektra, 2002. 109. p. Forrás: http://dia.jadox.pim.[-] $\mathrm{hu} /$ jetspeed $/$ displayXhtml?offset $=1 \&$ origOffset $=8 \&$ docId $=8475 \& \sec I d=855453 \& q d c[-]$ $\mathrm{Id}=3 \&$ libraryId=-1\&filter=Vasy + G\%C3\%A9za\&limit=10\&pageSet=1 [2016. január 20.]

${ }^{46}$ VASY Géza 2002. i. m. 110. p.

${ }^{47}$ TÜSKÉS Tibor: Illyés Gyula pályaképe. Pécs, Pro Pannonia, 2002. 336 p. Forrás: http://[-] dia.jadox.pim.hu/jetspeed/displayXhtml?offset=1\&origOffset $=2 \&$ docId=8473\&secId[-] $=855117 \&$ qdcId $=3 \&$ libraryId $=-1 \&$ filter $=\mathrm{T} \% \mathrm{C} 3 \% \mathrm{BCsk} \% \mathrm{C} 3 \% \mathrm{~A} 9 \mathrm{~s}+$ Tibor\&limit $=10[-]$ \&pageSet=1 [2016. január 25.]

${ }^{48}$ KOLOZSVÁRI GRANDPIERRE Emil: Árnyak az alagútban. Budapest, Magvető, 1981. 41. p.

${ }^{49}$ TÜSKÉS Tibor 2002. i. m.

${ }^{50}$ ILLYÉS Gyula: Naplójegyzetek 1946-60. Budapest, Szépirodalmi, 1987. 531 p. Forrás: http:/ / dia.jadox.pim.hu/jetspeed/displayXhtml?offset=1\&origOffset $=-1 \&$ docId $=883[-]$ \&secId $=82188 \& q d \mathrm{~d} I d=3 \&$ libraryId $=-1 \&$ filter $=$ Illy $\% \mathrm{C3} \%$ A9s + Gyula\&limit $=1000 \&[-]$ pageSet=1 [2016. január 25.]

${ }^{51}$ Közművelődési hírek. $=$ Új Szó, 3. évf. 48. sz. 1950. 5. p.

${ }^{52}$ ILLYÉS Gyula 1987. i. m., idézi SCHILLER Erzsébet: A Mai orosz dekameron szerkesztése 1935-1936. = Irodalomtörténeti Közlemények, 118. évf. 4. sz. 2014. 556. p.

${ }^{53}$ VASY Géza 2010. i. m. 32. p.

${ }^{54}$ TÉGLÁS János: Babits-epizódok 2. Budapest, Klauzál Gábor Mưszeripari Szakközépiskolaés Szakiskola, 2007. 101. p.

${ }^{55}$ Erről és az alapítvány előtörténetéről és lassú ellehetetlenítésérôl lsd. TÉGLÁS 2007. i. m. 67-129. p.; MURÁNYI Gábor: A húsz évet élt „örökalapítvány”. = Beszélő, 8. évf. 4. sz. 95-106. p. Forrás: http://beszelo.c3.hu/03/04/29muranyi.htm [2016. január 10.]

${ }^{56}$ MNL XIX-I-3-c 2. dob. 685. tétel.

${ }^{57}$ MNL i. m. 663. tétel.

${ }^{58}$ MNL XIX-I-3-e 6. dob. 1395. tétel.

${ }^{59}$ NÉMETH László 2002. i. m.

${ }^{60}$ ILLYÉS Gyula összegyüjtött versei. Budapest, Szépirodalmi, 1993. Forrás: http://dia.[-] jadox.pim.hu/jetspeed / displayXhtml? offset=1\&origOffset=-1\&docId=906\&secId=[-] 85662\&limit=10\&pageSet=1 [2016. január 25.]

${ }^{61}$ MNL XIX-I-3-c 2. dob. 685. tétel.

${ }^{62}$ DOMOKOS MÁTYÁS 1998. i. m. 103. p.

${ }^{63}$ ILLYÉS Gyula 1987. i. m.

${ }^{64}$ MNL XIX-I-3-c 2. dob. [tételszám nélkül] 1953. 


\section{„KÉREM, NE LEGYEN TÚL ÉRZÉKENY.” IRODALOMPOLITIKA ÉS KÖNYVKIADÁS \\ RÉVAI JÓZSEF MINISZTERSÉGE IDEJÉN}

${ }^{65}$ MNL XIX-I-3-e 6. dob. 1837. tétel.

${ }^{66}$ MNL XIX-I-3-e 2. dob. 1437. tétel.

${ }^{67}$ VADERNA Gábor: Nemzedékek, programok, lehetőségek. = Irodalomtörténet, 93. évf. 3. sz. 2012. 291. p.

${ }^{68}$ N. PÁL József: Modernség, progresszió, Ady Endre és az Ady-Rákosi vita. Jyväskylä, Pécs, University of Jyväskylä, Faculty of Humanities, Hungarian Studies, 2008. 75-76. p. Forrás: http://mek.oszk.hu/12400/12430/12430.pdf [2016. január 28.]

69 SZOLLÁTH Dávid: A forradalmi költőtriász. Forrás: http://real.mtak.hu/7651/1/A\%[-] 20forradalmi $\% 20 \mathrm{k} \% \mathrm{C} 3 \% \mathrm{~B} 61 \mathrm{t} \% \mathrm{C} 5 \% 91 \mathrm{tri} \% \mathrm{C} 3 \% \mathrm{~A} 1 \mathrm{sz} \_s z \% \mathrm{C} 3 \%$ B6veg.pdf [2016. január 28.]

${ }^{70}$ SCHEIBNER Tamás: Konfliktusok, kompromisszumok, szövetségek. = Irodalomtörténet, 93. évf. 3. sz. 2012. 308. p.

${ }^{71}$ MNL XIX-I-3-c 2. dob. 1081. tétel.

${ }^{72}$ MNL i. $\mathrm{m}$.

${ }^{73}$ MNL XIX-I-3-c 2. dob. 1265. tétel.

${ }^{74}$ URBÁN Károly: Révai, a kultúrdiktátor. = Rubicon, 4. évf. 7. sz. 1993. 10-13. p.

${ }^{75}$ MNL XIX-I-3-c 2. dob. [tételszám nélkül] 1951.

Bella Katalin az ELTE BTK Könyvtár- és Információtudományi Intézetének tanársegéde. Kutatásaiban az 1945 utáni könyvnyomtatás, könyvkiadás és irodalompolitika kérdéseit járja körül. Legújabban a legfontosabb könyvkiadók történetével foglalkozik. Tanszéki tevékenységének az oktatás mellett része az ERASMUS-koordinátori feladatok ellátása is. 